\title{
Improving Fifth-Grade Students' Mathematical Problem-Solving and Critical Thinking Skills Using Problem-Based Learning
}

\author{
Erif Ahdhianto $^{1,2, *}$, Marsigit ${ }^{3}$, Haryanto $^{3}$, Yogi Nurfauzi ${ }^{4}$ \\ ${ }^{1}$ Department of Educational Sciences, Yogyakarta State University, Indonesia \\ ${ }^{2}$ Department of Primary School Teacher Education, Universitas Nusantara PGRI Kediri, Indonesia \\ ${ }^{3}$ Graduate School, Yogyakarta State University, Indonesia \\ ${ }^{4}$ Department of Economic Education, Faculty of High School Teacher Training and Education, Stkip Majenang, Indonesia
}

Received February 25, 2020; Revised March 20, 2020; Accepted March 28, 2020

Copyright $\bigcirc 2020$ by authors, all rights reserved. Authors agree that this article remains permanently open access under the terms of the Creative Commons Attribution License 4.0 International License

\begin{abstract}
Although students' problem-solving and critical thinking skills have been set as the main goal of the mathematics subject, the results tend to be unsatisfactory. This study aims to improve students' mathematical problem-solving and critical thinking skills using problem-based learning (PBL). A quasi-experimental design was utilized in this study which involved 78 (31 males and 47 females) fifth-grade students as the sample. The students were divided into two groups, namely the experimental group $(n=39)$ and the control group $(n=39)$. This study was conducted in an Indonesian elementary school in its first semester of the 2019/2020 school year. The Problem-Solving Skills Test (PSST) and Critical Thinking Skills Test (CTST) were administered to obtain the data. One-Way MANOVA and ANOVA tests were used to analyze the data at a significance level of .05. The results showed that students in the experimental group had higher post-test scores compared to the control group in terms of mathematical problem-solving and critical thinking skills. Thus, it can be concluded that PBL effectively promoted fifth-grade students' problem-solving and critical thinking skills.
\end{abstract}

Keywords Critical Thinking Skills, Mathematical Problem-Solving Skills, Problem-Based Learning, Elementary School Students

\section{Introduction}

Mathematical problem-solving and critical thinking skills are two essential skills in learning mathematics in the twenty-first century. Problem-solving skills are part of the transferable skills that students need to work with other students to find, analyze, synthesize, and apply knowledge to new situations [1]. Furthermore, Jitendra et al. [2] defined problem-solving as a process of designing a strategy and completing steps to solve a problem. Some literature showed that problem-solving is associated with how students are actively involved in solving mathematical problems that support the development of their problem-solving competencies [3,4]. The importance of improving problem-solving skills was stated by Andrews and Xenofontos [5] that these essential skills are needed by students to evaluate mathematical information and solve problems in daily life. NCTM [3] suggested that teachers develop students' mathematical problem-solving early. Thus, problem-solving skills are required to be possessed by children from the elementary school level.

Although problem-solving skills affect academic achievement, school success individual relationships, self-explanation quality, motivation, and mathematical abilities [6-9], previous researches indicated that students' problem-solving skills are inadequate and tend to decrease from year to year [10,11]. Lee, Yeo, and Hong [12] reported that many fourth-grade students have difficulty in starting the process of solving mathematical problems because it requires knowledge and perseverance [8]. Moreover, students generally only learn to solve structured tasks related to the subject matter [13,14]. Structured assignments are limited to exercises to evaluate students' initial knowledge of the material they have recently learned [15]. Thus, it is important to train students to complete non-routine tasks using effective teaching methods to be successful in and outside the classroom.

Besides developing elementary students' problem-solving skills, improving critical thinking skills is 
one of the main goals in education [16], including learning mathematics in elementary schools. Ennis, Millman, and Tomko [17] defined critical thinking (CT) as a sensible and reflective thinking that focuses on deciding what to do. This is an assessment process directed by a certain final goal to arrive at a logical and rational solution to the problem [18,19]. Moreover, critical thinking is seen as a thinking process where individuals are taught to reason in improving creative solutions [20]. Theoretically speaking, CT is divided into two types; skills and dispositions. CT skills include a set of higher-order thinking skills such as evaluating, inferring and analyzing. Additionally, CT disposition includes self-confidence, open-mindedness, and truth-seeking [19,21]. Specifically, in this study, the researchers investigated students' CT skills in learning mathematics in elementary school. Lundy et al. [22] stated that critical thinking can be developed by utilizing critical thinking learning techniques.

However, some previous studies revealed that students' critical thinking tends to be unsatisfactory [23,24], even in some empirical research. For example, Akgun and Duruk [25] found that students' critical thinking was at a low level. Similarly, Bakir [26] also reported inadequate critical thinking among students. In fact, critical thinking is closely related to academic achievement [27,28], writing ability [29], questioning behaviors [30], and interpersonal skills [31]. Literature showed that critical and creative thinking are connected [32]. Brahler, Quitadamo, and Johnson [33] revealed that critical thinking skill is related to various variables; learning environment, social context of learning and instructor's teaching style. Thus, teachers need to train students in improving their critical thinking skills using instructional strategies that stimulate students to think critically.

To deal with these problems, the teacher can support student learning by providing strategies that free students to think at a high level and solve problems [1]. Various teaching models to improve problem-solving skills and critical thinking in class have been suggested. However, problem-based learning (PBL) is considered as the most powerful learning method [34]. PBL is the opposite of traditional pedagogy that gives students more opportunities to set learning goals, adopt learning steps, and construct meaningful knowledge [34]. In this context, PBL presents students with problems or situations to apply prior knowledge and obtain new knowledge. There are five steps in the PBL process: problem analysis, setting learning objectives, gathering information, summarizing, and reflecting [35]. In PBL, students face problem-solving situations in small groups. In groups, the students are required to decide the information they need to identify the situation in question, try to understand it, present it to other students, and then reformulate it to be able to overcome the problems [36].
PBL is a student-centered approach under the principles of constructivist learning theory [37]. Previous research has explained that children enjoy PBL due to their curiosity [38]. The acquisition of knowledge is one of the prerequisites in developing students' critical thinking skills [37,39]. From this perspective, the teacher's role is to provide children with appropriate concepts, materials, and resources to enable them to explore their interests and to design new understandings [40]. PBL is acknowledged to be able to contribute to factors such as knowledge retention, student satisfaction, motivation, and critical thinking. Herman and Knobloch [41] recommended future studies to investigate the use of constructivist PBL approaches to determine effects on learning outcomes.

As a strategy for mathematics teaching organizations, PBL allows students to present their creative ideas and communicate mathematically with peers [42-44]. Besides, PBL makes learning meaningful and makes learners develop several important skills [45]. Several studies had examined the use of PBL as a teaching method to improve student learning, but the findings vary. Previous studies proved that PBL is effective in increasing environmental attitudes, academic achievement, self-regulated learning, and science process skills compared to the traditional teaching approach [46-49]. Moreover, studies in mathematics education reported that students in the PBL environment have better performance in conceptual understanding and long-term knowledge retention than those in teacher-centered classes [34,50]. However, the use of PBL to promote students' transferable skills in primary schools is rarely explored. Thus, this study focused on exploring the effects of PBL to foster students' problem-solving and critical thinking skills in mathematics at the primary level.

\subsection{Objectives of the Study}

The researchers believed that PBL can involve students in math subjects and have an impact on increasing students' transferable skills. Therefore, this study aims to evaluate the effect of PBL in improving the problem-solving and critical thinking skills of fifth-grade students. The formulated research question is:

1. Is there any significant difference between groups exposed to PBL and traditional instruction in terms of problem-solving skills in mathematics?

2. Is there any significant difference between groups exposed to PBL and traditional instruction in terms of critical thinking skills in mathematics?

3. Is there any significant difference between groups exposed to PBL and traditional instruction with respect to combine dependent variables of problem-solving skills and critical thinking skills in mathematics? 


\section{Methods}

\subsection{Research Design}

A quasi-experimental non-equivalent control group design was used in this study (see Table 1). The intervention involved 2 intact classes in an Indonesian public elementary school. One class was assigned as an experimental group and another class as a comparison group using simple random sampling techniques. This study was conducted from November to December 2019 in the 2019/2020 academic year.

Table 1. Pre-test and post-test control group design

\begin{tabular}{|c|c|c|c|}
\hline Groups & Pre-tests & Treatments & Post-tests \\
\hline \multirow{2}{*}{ Experimental } & PSST & \multirow{2}{*}{ Problem-based learning } & PSST \\
& CTST & & CTST \\
\hline \multirow{2}{*}{ Control } & PSST & \multirow{2}{*}{ Conventional teaching } & PSST \\
& CTST & & CTST \\
\hline
\end{tabular}

\subsection{Research Sample}

A total of 78 (31 males and 47 females) fifth-grade elementary school students (aged 11-12 years at
Ganungkidul Elementary School, Nganjuk, Indonesia participated as the sample of this study. All students were randomly divided into experimental group $(n=39 ; 17$ males and 22 females) and control group $(n=39 ; 14$ males and 25 females). Students in the experimental group were taught using the PBL model and the control group was taught using a conventional learning model. All students had an equal socio-economic and educational background. They lived in urban areas and came from middle to upper-income families. All students were instructed by 1 female teacher with teaching experience of more than 10 years. The teacher held a B.Ed. degree from a local university. Before treatment, the teacher was given directions to apply different learning models.

\subsection{Research Instruments}

\subsubsection{Problem-Solving Skills Test (PSST)}

The PSST includes 4 sub-scales adapted from Polya [51], including understanding the problem, making a solution plan, solving the problem according to the plan, and concluding. In detail, the scoring rubric for problem-solving skills is presented in Table 2 .

Table 2. Rubric for the problem-solving skills test

\begin{tabular}{|c|c|c|}
\hline Sub-skills & Score & Scoring Criteria \\
\hline \multirow{3}{*}{ Understanding the Problem } & 2 & The student writes their understanding and their problem from the problem raised clearly. \\
\hline & 1 & $\begin{array}{l}\text { The student writes their understanding and their problem but not related to the problem raised } \\
\text { which make them do not understand the problem rose. }\end{array}$ \\
\hline & 0 & The student does not write anything which makes them do not understand the problem rose. \\
\hline \multirow{3}{*}{$\begin{array}{l}\text { Making a Plan to Solve the } \\
\text { Problem }\end{array}$} & 2 & $\begin{array}{l}\text { The student writes down plans and necessary conditions (formulas) needed to solve the } \\
\text { problems raised and use all the information that has been collected. }\end{array}$ \\
\hline & 1 & The student writes down a plan to solve the problem raised but not coherently \\
\hline & 0 & The student does not write plans to solve problems \\
\hline \multirow{5}{*}{$\begin{array}{l}\text { Solving the Problem } \\
\text { According to the Plan }\end{array}$} & 4 & $\begin{array}{l}\text { The student solves the problems according to plans that have been made precisely. There are no } \\
\text { procedural and calculation errors. }\end{array}$ \\
\hline & 3 & $\begin{array}{l}\text { The student solves the problems according to plans that have been made. There is no procedural } \\
\text { error, but calculation errors occurred. }\end{array}$ \\
\hline & 2 & $\begin{array}{l}\text { The student solves problems according to plans that have been made, but there are procedural } \\
\text { and calculation errors. }\end{array}$ \\
\hline & 1 & $\begin{array}{l}\text { The student solves problems according to plans that have been made, but there are procedural } \\
\text { errors and calculation errors. }\end{array}$ \\
\hline & 0 & The student does not solve the problems according to plans that have been made. \\
\hline \multirow{3}{*}{ Concluding } & 2 & The student concludes following the problem and the results. \\
\hline & 1 & The student concludes but does not follow the problem and results \\
\hline & 0 & The Student does not make any conclusions. \\
\hline
\end{tabular}


Initially, the PSST consisted of 6 items in the form of a description. Each question had been adjusted to basic competencies and indicators as regulated in the Indonesian elementary school curriculum [52]. Then, PSST was validated by 2 mathematics teaching experts. Validation relates to (1) the suitability of the questions with the indicators, (2) the level of difficulty of the questions, (3) the use of language, and (4) the truth of the concept. After the validation, PSST was then tested to 30 fifth-grade students at Sugihwaras Elementary School in the pilot study. Based on the try out results, 4 questions were declared valid and 2 questions were invalid (see Table 3). The analysis showed that the reliability coefficient of the test was found at .71.
Table 3. Items validity of the problem-solving skills test

\begin{tabular}{|c|c|c|c|c|}
\hline Items & $\boldsymbol{r}_{\text {observed }}$ & $\boldsymbol{r}_{\text {table }} \mathbf{5 \%}(\boldsymbol{n}=\mathbf{3 0})$ & $\boldsymbol{p}$ & Criteria \\
\hline Item 1 & .707 & .361 & .000 & Valid \\
\hline Item 2 & .075 & .361 & .695 & Invalid \\
\hline Item 3 & .633 & .361 & .000 & Valid \\
\hline Item 4 & .345 & .361 & .062 & Invalid \\
\hline Item 5 & .749 & .361 & .000 & Valid \\
\hline Item 6 & .676 & .361 & .000 & Valid \\
\hline
\end{tabular}

\subsubsection{Critical Thinking Skills Test (CTST)}

The CTST was adapted from Ennis [53]. The scoring rubric for students' critical thinking skills is presented in Table 4.

Table 4. Rubric for the critical thinking skills test

\begin{tabular}{|c|c|c|c|}
\hline Sub-skills & Indicator & Score & Scoring Criteria \\
\hline \multirow{3}{*}{ Focus } & \multirow{3}{*}{ The ability to identify the problem } & 2 & The student writes their understanding and the problem correctly \\
\hline & & 1 & $\begin{array}{l}\text { The student writes their understanding and the problem but the answers are } \\
\text { not quite right }\end{array}$ \\
\hline & & 0 & No answer \\
\hline \multirow{3}{*}{ Reason } & \multirow{3}{*}{ The ability to do the reasoning } & 2 & The student writes answers by giving the right reasons \\
\hline & & 1 & The student writes answers with incorrect reasons \\
\hline & & 0 & No answer \\
\hline \multirow{3}{*}{ Inference } & \multirow{3}{*}{ The ability to draw the conclusion } & 2 & The student concludes precisely \\
\hline & & 1 & The student concludes but it is not right \\
\hline & & 0 & No answer \\
\hline \multirow{3}{*}{ Clarity } & \multirow{3}{*}{$\begin{array}{l}\text { The ability to check and ensure } \\
\text { the clarity of thought }\end{array}$} & 2 & The student can identify problems, answers, and conclude clearly \\
\hline & & 1 & The student identifies problems, answers, and concludes, but not clearly \\
\hline & & 0 & Students' problem identification, answers, and conclusions are unclear \\
\hline
\end{tabular}


Initially, CTST consisted of 6 items in the form of description. Furthermore, CTST was tested on 30 fifth-grade students at Sugihwaras Elementary School, Indonesia. The try out results were analyzed through the calculation of Product Moment correlation. Rubric validity test results are declared valid if $r_{\text {calculated }} \geq .361$. Based on the tryout, 3 questions were declared valid, and 3 other questions were invalid (see Table 5). Moreover, the reliability coefficient was found at .78. Thus, CTST was declared valid and reliable.

Table 5. Items validity of the critical thinking skills test

\begin{tabular}{|c|c|c|c|c|}
\hline Items & $\boldsymbol{r}_{\text {calculated }}$ & $\boldsymbol{r}_{\text {table }} \mathbf{5 \%}(\boldsymbol{n}=\mathbf{3 0})$ & $\boldsymbol{p}$ & Criteria \\
\hline Item 1 & .346 & .361 & .061 & Invalid \\
\hline Item 2 & .839 & .361 & .000 & Valid \\
\hline Item 3 & .651 & .361 & .000 & Valid \\
\hline Item 4 & .131 & .361 & .489 & Invalid \\
\hline Item 5 & .595 & .361 & .001 & Valid \\
\hline Item 6 & .842 & .361 & .000 & Valid \\
\hline
\end{tabular}

\subsection{Procedures}

After obtaining official permission from the Nganjuk Education Office and the school principal, students and parents were given a consent form. In this study, all students participate voluntarily and they could withdraw at any time. After they signed the consent form, a pre-test was conducted. After the pre-test, the experimental and control group students participated in learning activities for 3 meetings ( $3 \times 105 \mathrm{~min}=315 \mathrm{~min}$ in total). Students in the experimental group were instructed to use the problem-based learning model and students in the control group used the conventional learning model.

\subsubsection{Intervention in Experimental Group}

Learning activities in experimental groups used problem-based learning adapted from Arends [54]. The learning process involved the following steps: (1) introducing students to real problems where the teacher conveyed the main material and learning objectives, apperception with questions and answers from the previous material; (2) organizing students to learn where the teacher organized students to form study groups; (3) helping independent and group investigations in which the teacher encouraged students to identify problems, discuss/exchange ideas according to their prior knowledge, and solve problems; (4) developing and presenting the work where students presented the results of the discussion and the teacher acted as a facilitator in the discussion; and (5) analyzing and evaluating the problem-solving process where students were assisted by teachers to analyze and evaluate their thinking processes in investigations and the intellectual skills used when solving problems and reflecting on learning.

\subsubsection{Intervention in the Control Group}

Learning activities in the control group used conventional learning. In this method, the teacher acted as an active messenger of information and students as passive listeners. Some learning steps taken during the intervention were the teacher leading the prayers, checking the attendance list, giving apperception, and conveying the learning objectives. After that, the teacher conveyed information and explained learning the material on the board, and then students took notes. The teacher gave lower-order thinking skills questions and students worked on the problems independently. Then, students were asked to answer the questions and the other students to do peer review. Finally, the teacher concluded the topic and assigned independent assignments for discussion at the next meeting.

\subsection{Data Analysis}

In this study, the data were analyzed using inferential statistics. Before employing inferential statistics, the prerequisite tests were normality and homogeneity tests. The Kolmogorov-Smirnov test and the Shapiro-Wilks test [55] were used for the normality test. The analysis showed that the data were normally distributed (see Table 6).

Table 6. Kolmogorov-Smirnov and Shapiro-Wilk test results

\begin{tabular}{|c|c|c|c|c|c|c|c|c|}
\hline & \multirow{2}{*}{\multicolumn{2}{|c|}{ Groups }} & \multicolumn{3}{|c|}{ Kolmogorov-Smirnov } & \multicolumn{3}{|c|}{ Shapiro-Wilk } \\
\hline & & & Statistic & $d f$ & $p$ & Statistic & $d f$ & $p$ \\
\hline \multirow{4}{*}{ Problem-Solving Skills } & \multirow{2}{*}{ Experimental } & Post-test & .113 & 39 & .200 & .972 & 39 & .437 \\
\hline & & Pre-test & .087 & 39 & .200 & .977 & 39 & .598 \\
\hline & \multirow{2}{*}{ Control } & Post-test & .096 & 39 & .200 & .973 & 39 & .454 \\
\hline & & Pre-test & .121 & 39 & .155 & .960 & 39 & .175 \\
\hline \multirow{4}{*}{ Critical Thinking Skills } & \multirow{2}{*}{ Experimental } & Post-test & .092 & 39 & .200 & .970 & 39 & .367 \\
\hline & & Pre-test & .089 & 39 & .200 & .967 & 39 & .298 \\
\hline & \multirow{2}{*}{ Control } & Post-test & .086 & 39 & .200 & .962 & 39 & .205 \\
\hline & & Pre-test & .115 & 39 & .200 & .963 & 39 & .230 \\
\hline
\end{tabular}


Table 7. Box's $M$ test results from the pre-test scores

\begin{tabular}{|c|c|c|c|c|c|c|}
\hline Dependent Variables & $n$ & Box's $M$ & $\boldsymbol{F}$ & $d f 1$ & $d f 2$ & $p$ \\
\hline Problem-Solving Skills & 39 & \multirow{2}{*}{.658} & \multirow{2}{*}{.213} & \multirow{2}{*}{3} & \multirow{2}{*}{1039680} & \multirow{2}{*}{.887} \\
\hline Critical Thinking Skills & 39 & & & & & \\
\hline
\end{tabular}

Table 8. Box's $M$ test results from the post-test scores

\begin{tabular}{|c|c|c|c|c|c|c|}
\hline Dependent Variables & $n$ & Box's $M$ & $\boldsymbol{F}$ & $d f 1$ & $d f 2$ & $p$ \\
\hline Problem-Solving Skills & 39 & \multirow{2}{*}{1.427} & \multirow{2}{*}{.462} & \multirow{2}{*}{3} & \multirow{2}{*}{1039680} & \multirow{2}{*}{.709} \\
\hline Critical Thinking Skills & 39 & & & & & \\
\hline
\end{tabular}

After that, the matrix covariance pre-test was conducted. The results of the matrix covariance test indicate that the Box's $M$ values in both variables had a significant number greater than .05 (see Table 7). Thus, it can be concluded that the variance-covariance matrices of the dependent variable were assumed to be equal.

Then, the post-test matrix covariance test was performed. The results of the matrix covariance test indicate that the Box's $M$ values in both variables had a significant number greater than .05 (see Table 8). Therefore, it can be concluded that the variance-covariance matrices of the dependent variable were assumed to be equal.

Moreover, the homogeneity test of variance between groups was conducted using Levene's test of equality of error variance [55]. The results of the pre-test analysis showed that the homogeneity of the variance was not violated (see Table 9). Thus, the assumption test had been achieved.

Table 9. Levene's test results of pre-test scores

\begin{tabular}{|c|c|c|c|c|}
\hline Dependent Variables & $\boldsymbol{F}$ & $\boldsymbol{d} \boldsymbol{f} \mathbf{1}$ & $\boldsymbol{d} \boldsymbol{f} \boldsymbol{2}$ & $\boldsymbol{p}$ \\
\hline Problem-Solving Skills & .548 & 1 & 76 & .462 \\
\hline Critical Thinking Skills & .193 & 1 & 76 & .662 \\
\hline
\end{tabular}

Next, the homogeneity test of variance between groups in the post-test was also conducted using Levene's test of Equality of Error Variance [55]. The results of the post-test analysis showed that the homogeneity of the variance was not violated (see Table 10). Thus, the assumption test had been achieved.

Table 10. Levene's test results of post-test scores

\begin{tabular}{|c|c|c|c|c|}
\hline Dependent Variables & $\boldsymbol{F}$ & $\boldsymbol{d} \boldsymbol{f} \mathbf{1}$ & $\boldsymbol{d} \boldsymbol{f} \mathbf{2}$ & $\boldsymbol{p}$ \\
\hline Problem-Solving Skills & .504 & 1 & 76 & .480 \\
\hline Critical Thinking Skills & .010 & 1 & 76 & .922 \\
\hline
\end{tabular}

After that, the one-way Multivariate Analysis of Variance (MANOVA) was performed to investigate the effect of the problem-based learning model on students' problem-solving and critical thinking skills. Then, an analysis of variance (ANOVA) was used to determine differences between groups' mean scores in the post-test. In this study, SPSS version 25 was used to analyze data at a significance level of .05 .

\section{Results}

One-way ANOVA statistical test was used to determine the differences of pre-test mean scores between the experimental and control groups in terms of problem-solving and critical thinking skills. The results are shown in Table 11.

According to Table 11, there were no significant differences in the pre-test scores between the experimental and control groups in terms of problem-solving skills $(F=$ $2.154, p>0,05)$ and critical thinking skills $(F=1.525, p>$ $0,05)$. This indicates that both groups had equal initial skills.

Table 11. One-way ANOVA results for pre-test mean scores

\begin{tabular}{|c|c|c|c|c|c|c|}
\hline Dependent Variables & Groups & $M$ & $S D$ & $d f$ & $\boldsymbol{F}$ & $p$ \\
\hline \multirow{2}{*}{ Problem-Solving Skills } & Experimental & 57.64 & 10.34 & \multirow{2}{*}{1} & \multirow{2}{*}{2.154} & \multirow{2}{*}{.146} \\
\hline & Control & 54.36 & 9.76 & & & \\
\hline \multirow{2}{*}{ Critical Thinking Skills } & Experimental & 58.67 & 9.96 & \multirow{2}{*}{1} & \multirow{2}{*}{1.525} & \multirow{2}{*}{.221} \\
\hline & Control & 55.79 & 10.57 & & & \\
\hline
\end{tabular}


Table 12. One-way ANOVA results for post-test mean scores

\begin{tabular}{|c|c|c|c|c|c|c|}
\hline Dependent Variables & Groups & $M$ & $S D$ & $d f$ & $F$ & $p$ \\
\hline \multirow{2}{*}{ Problem-Solving Skills } & Experimental & 77.13 & 10.55 & \multirow{2}{*}{1} & \multirow{2}{*}{30.569} & \multirow{2}{*}{.000} \\
\hline & Control & 62.97 & 11.89 & & & \\
\hline \multirow{2}{*}{ Critical Thinking Skills } & Experimental & 76.74 & 10.90 & \multirow{2}{*}{1} & \multirow{2}{*}{22.050} & \multirow{2}{*}{.000} \\
\hline & Control & 64.83 & 11.48 & & & \\
\hline
\end{tabular}

After that, the ANOVA statistical test was used to test the first and second research questions. It was also used to explore univariate main effects of learning models on the dependent variables. The results of the analysis of the influence of instructional models on students' problem-solving and critical thinking skills are presented in Table 12.

Table 12 showed the average score of the students' problem-solving skills during the post-test in the experimental group $(M=77.13 ; S D=10.55)$ was significantly higher compared to the control group $(M=$ 62.97; than their counterparts $(M=64.83 ; S D=11.48)$ in terms of critical thinking skills. In short, there were significant mean differences in problem-solving $[F(1,202)$ $=30.569 ; p<.05]$ and critical thinking skills $[F(1,202)=$ $22.050 ; p<.05]$ between the two groups. These findings imply that treatment differences affect the average post-test scores between experimental and control group students.

Table 13. Results of one-way MANOVA for pre-test scores

\begin{tabular}{|c|c|c|c|c|c|}
\hline Effect & Value & $\boldsymbol{F}$ & $\boldsymbol{d} \boldsymbol{f}$ & Error $\boldsymbol{d} \boldsymbol{f}$ & $\boldsymbol{p}$ \\
\hline Pillai's Trace & .028 & 1.083 & 2.000 & 75.000 & .344 \\
\hline Wilks' Lambda & .972 & 1.083 & 2.000 & 75.000 & .344 \\
\hline Hotelling's Trace & .029 & 1.083 & 2.000 & 75.000 & .344 \\
\hline Roy's Largest Root & .029 & 1.083 & 2.000 & 75.000 & .344 \\
\hline
\end{tabular}

According to Table 13, the results of the MANOVA test in the pre-test indicate that there were no statistically significant differences between the experimental and control groups in terms of combined dependent variables of problem-solving and critical thinking $[F(2,201)=1.083$, $p<0,05$; Wilks' Lambda $=.726]$. Based on the pre-test scores between the experimental and control groups, both groups had equal initial skills.

Then, the third research question was, "Is there a significant effect of PBL on the combined dependent variables of problem-solving and critical thinking skills?" One-Way MANOVA was run for post-test scores. The details of the MANOVA test results are presented in Table 14.

Table 14. Results of one-way MANOVA for post-test scores

\begin{tabular}{|c|c|c|c|c|c|}
\hline Effect & Value & $\boldsymbol{F}$ & $\boldsymbol{d} \boldsymbol{f}$ & Error $\boldsymbol{d} \boldsymbol{f}$ & $\boldsymbol{p}$ \\
\hline Pillai's Trace & .310 & 16.864 & 2.000 & 75.000 & .000 \\
\hline Wilks' Lambda & .690 & 16.864 & 2.000 & 75.000 & .000 \\
\hline Hotelling's Trace & .450 & 16.864 & 2.000 & 75.000 & .000 \\
\hline $\begin{array}{c}\text { Roy's Largest } \\
\text { Root }\end{array}$ & .450 & 16.864 & 2.000 & 75.000 & .000 \\
\hline
\end{tabular}

Based on Table 14, the results showed that there were statistically significant mean differences between the experimental and control groups in terms of combined dependent variables of problem-solving and critical thinking after the intervention $[F(2,201)=16.864, p<$ $0,05$; Wilks' Lambda $=.726]$. These findings indicate that the difference in post-test scores between the experimental and control groups was due to the treatment effect. It can be concluded that there is an effect of PBL on mathematical problem-solving and critical thinking skills.

\section{Discussion and Conclusions}

This study had examined the effect of problem-based learning (PBL) on fifth-grade students' mathematical problem-solving and their critical thinking skills compared to conventional learning. MANOVA test results showed that students who learned using PBL obtained better post-test scores than those who used conventional learning. It can be said that learning using PBL is effectively used to catalyze mathematics learning in elementary schools. This might be the impact of the implementation of the problem-based learning model, where student-centered learning was designed to increase the active involvement of students and their active participation during learning. Moreover, the tasks and problems presented were related to students' daily lives. Darling-Hammond et al. [1] agreed that a learning environment that allows teachers to make connections between new situations and the daily world of students is believed to be able to promote problem-solving skills.

Separately, the ANOVA results also showed that students taught using PBL scored higher scores on mathematical problem-solving skills than those taught using conventional teaching models. Increasing student problem-solving skills might be due to the teacher always creating active and fun learning through group discussions. In a student-centered learning environment, students are always provided with the opportunity to ask questions that are relevant to the learning material and relate it to their real life. Thus, the learning process can stimulate students to develop their problem-solving skills. This argument was supported by Ultay [56] who stated that problems that allow students to analyze, synthesize, and evaluate, are claimed to improve their problem-solving skills. Supportively, the current findings are in line with several previous studies that stated that PBL produces clear 
benefits for students including improving their problem-solving skills [57,58].

Whereas, the ANOVA results showed that students who were taught with PBL had better scores on critical thinking skills than those taught in a teacher-centered approach. During the treatment process, PBL learning models can increase peer interaction to construct their critical thinking skills. Then, students in PBL courses were more likely to define problems and consider alternative solutions to complete unstructured tasks [59]. Unlike the chalk and talk method, PBL emphasizes student-centered learning. In this context, the teacher acts as a facilitator who provides students with high-level questions and non-routine problems. In the end, learning becomes more meaningful and makes learners develop their skills to think critically [45]. This study was supported by previous research related to implementing PBL to improve critical thinking skills which have shown positive results $[60,61]$.

In short, the pre-test and post-test results obtained from the experimental and control groups showed a change in the problem-solving and critical thinking scores for the two groups. However, a statistically significant increase was found in the experimental group. These findings indicate that the experimental group developed better transferable skills after the intervention using PBL. Students' high post-test scores in this study might be due to the PBL facilitating students to learn mathematical concepts by connecting topics with the daily life context [13]. In this study, students' problem-solving skills develop well when teachers associate learning with their real-life situations [62]. This finding is supported by Pedersen and Lio [59] who claimed that during PBL, students successfully develop problem-solving skills and then transfer themselves to other situations. On the other hand, the high score of critical thinking skills is related to the opportunities students get and the interaction between students and the learning environment during the intervention $[63,64]$.

Previous literature believed that PBL is an effective instrument in acquiring student knowledge $[65,66]$. Increasing students' thinking during PBL can help them to participate more effectively in the learning environment and ultimately develop problem-solving skills [59]. At the same time, they also develop students' critical thinking skills [67]. Similarly, the study results reported by Argaw, Haile, Ayalew, and Kuma [68] also showed that PBL significantly promoted students' problem-solving skills. Thus, teachers need to involve students in PBL to complete assignments and problems inside and outside the classroom. This is because PBL can influence the problem-solving process brought by students to successfully face the problems [59]. Moreover, to make mathematics more meaningful for students, Gilbert [69] even emphasized the importance of real-world contexts to be designed in such a way as to engage students in teaching and learning.
In conclusion, the experimental group students had higher post-test scores than the control group in terms of problem-solving, critical thinking skills, and combined dependent variables. In addition, experimental group students showed higher score changes than their counterparts at the end of the treatment. This finding indicates that treatment differences affect the mean post-test scores between students in both groups. It can be concluded that PBL has succeeded in improving fifth-grade students' problem-solving and critical thinking skills in mathematics.

However, this study has several limitations. First, this study only investigated the effect of PBL on limited mathematical topics, distance, speed, and discharge. Moreover, the instruction was carried out over three sessions. Thus, long-term research is needed to study changes in student performance over time. Second, this study explored the problem-solving and critical thinking skills of fifth-grade students only. Therefore, further research needs to evaluate the effect of PBL on other variables, for example, academic achievement, motivation, attitude toward mathematics, self-efficacy, and higher-level thinking skills, both quantitatively and qualitatively. This aims to add scientific evidence of the efficacy of PBL at the primary level which lacks attention.

\section{REFERENCES}

[1] Darling-Hammond, L., Flook, L., Cook-Harvey, C., Barron, B., \& Osher, D. (2019). Implications for educational practice of the science of learning and development. Applied Developmental Science, 1-44.

[2] Jitendra, A. K., Griffin, C. C., McGoey, K., Gardill, M. C., Bhat, P., \& Riley, T. (1998). Effects of mathematical word problem solving by students at risk or with mild disabilities. Journal of Educational Research, 91, 345-355.

[3] National Council of Teachers of Mathematics (NCTM). (2000). Principles and standards for school mathematics. Reston, VA: National Council of Teachers of Mathematics.

[4] Niss, M. (2003). The mathematical competencies and the learning of mathematics: The Danish KOM project. In A. Gagatsis \& S. Papastavridis (Eds.), Proceedings of the 3rd Mediterranean Conference on mathematics education (pp. 115-124). Athens, Greece: Hellenic Mathematical Society.

[5] Andrews, P., \& Xenofontos, C. (2014). Analysing the relationship between the problem-solving-related beliefs, competence and teaching of three Cypriot primary teachers. Journal of Mathematics Teacher Education, 18(4), 299325 .

[6] Beyazsacli, M. (2016). Relationship between problem solving skills and academic achievement. The Anthropologist, 25(3), 288-293.

[7] Delice, A., \& Ergene, O. (2015). Investigation of solving process in integral volume problems within personal relationship; disk, washer and shell methods. Sakarya University Journal of Science, 19, 37-54. 
[8] Liu, Z., Zhi, R., Hicks, A., \& Barnes, T. (2017). Understanding problem solving behavior of 6-8 graders in a debugging game. Computer Science Education, 27(1), 129.

[9] Szabo, A., \& Andrews, P. (2017). Uncovering the relationship between mathematical ability and problem solving performance of Swedish upper secondary school students. Scandinavian Journal of Educational Research, 62(4), 555-569.

[10] Steiner, T., Belski, I., Harlim, J., Baglin, J., Ferguson, R., \& Molyneaux, T. (2011). Do we succeed in developing problem-solving skills? The engineering students' perspective. In Y. M. Al-Abdeli \& E. Lindsay (Eds.), Proceedings of the 2011 AAEE Conference (pp. 389-395). Freemantle, Australia.

[11] Werner, L., Denner, J., Campe, S., \& Kawamoto, D. C. (2012). The fairy performance assessment: measuring computational thinking in middle school. In Proceedings of the 43rd ACM technical symposium on Computer Science Education (pp. 215-220). Raleigh, NC: ACM.

[12] Lee, N. H., Yeo, D. J. S., \& Hong, S. E. (2014). A metacognitive-based instruction for primary four students to approach non-routine mathematical word problems. ZDM Mathematics Education, 46(3), 465-480.

[13] Johnson, E. B. (2011). Contextual teaching and learning menjadikan kegiatan belajar mengajar mengasyikkan dan bermakna. Bandung: MLC.

[14] Yu, K.-C., Fan, S.-C., \& Lin, K.-Y. (2014). Enhancing students' problem-solving skills through context-based learning. International Journal of Science and Mathematics Education, 13(6), 1377-1401.

[15] Özcan, Z. Ç. (2015). The relationship between mathematical problem-solving skills and self-regulated learning through homework behaviours, motivation, and metacognition. International Journal of Mathematical Education in Science and Technology, 47(3), 408-420.

[16] Irwanto, Saputro, A. D., Rohaeti, E., \& Prodjosantoso, A. K. (2018). Promoting critical thinking and problem solving skills of preservice elementary teachers through process-oriented guided-inquiry learning (POGIL). International Journal of Instruction, 11(4), 777-794.

[17] Ennis, R. H., Millman, J., \& Tomko, T. N. (2005). The Cornell Critical Thinking Tests, Level $X$ and Z. Pacific Grove, California: Midwest Publications.

[18] Bailin, S., Case, R., Coombs, J. R., \& Daniels, L. B. (1999). Conceptualizing critical thinking. Journal of Curriculum Studies, 31(3), 285-302.

[19] Facione, P. A. (2007). Critical thinking: What it is and why it counts. Millbrae, CA: Insight Assessment.

[20] Paul, R., \& Elder, L. (2003). The Miniature Guide to Critical Thinking: Concepts and Tools. California: The Foundation for Critical Thinking.

[21] Ennis, R. H. (1989). Critical thinking and subject specificity: clarification and needed research. Educational Researcher, 18(3), 4-10.

[22] Lundy, L. K., Irani, T. A., Ricketts, J. C., Eubanks, E. E., Rudd, R. D., Gallo-Meagher, M., \& Fulford, S. G. (2002). A mixed-methods study of undergraduate dispositions toward thinking critically about biotechnology. Paper presented at the National Agricultural Education Research Conference, Las Vegas, NV.

[23] Alper, A. (2010). Critical thinking disposition of preservice teachers. Education and Science, 35(158), 14-27.

[24] Irwanto, Rohaeti, E., \& Prodjosantoso, A. K. (2019). Analyzing the relationships between preservice chemistry teachers' science process skills and critical thinking skills. Journal of Turkish Science Education, 16(3), 299-313.

[25] Akgün, A., \& Duruk, U. (2016). The investigation of preservice science teachers' critical thinking dispositions in the context of personal and social factors. Science Education International, 27(1), 3-15.

[26] Bakır, S. (2015). Critical thinking disposositions of preservice teachers. Educational Research and Review, $10(2), 225-233$.

[27] Stark, E. (2012). Enhancing and assessing critical thinking in a psychological research methods course. Teaching of Psychology, 39(2), 107-112.

[28] Williams, R. L., Oliver, R., Allin, J. L., Winn, B., \& Booher, C. S. (2003). Psychological critical thinking as a course predictor and outcome variable. Teaching of Psychology, 30(3), 220-223.

[29] Afshar, H. S., Movassagh, H., \& Arbabi, H. R. (2017). The interrelationship among critical thinking, writing an argumentative essay in an L2 and their subskills. The Language Learning Journal, 45(4), 419-433.

[30] Şeker, H., \& Kömür, S. (2008). The relationship between critical thinking skills and in-class questioning behaviours of English language teaching students. European Journal of Teacher Education, 31(4), 389-402.

[31] Deal, K. H. (2004). The relationship between critical thinking and interpersonal skills. The Clinical Supervisor, 22(2), 3-19.

[32] Treffinger, D. J., Isaksen, S. G., \& Dorval, B. K. (2006). Creative problem solving: An introduction. Waco, TX: Prufrock Press.

[33] Brahler, C. J., Quitadamo, I. J., \& Johnson, E. C. (2002). Student critical thinking is enhanced by developing exercise prescriptions using online learning modules. Advances in Physiology Education, 26(3), 210-221.

[34] Li, H.-C., \& Tsai, T.-L. (2017). The implementation of problem-based learning in a Taiwanese primary mathematics classroom: lessons learned from the students' side of the story. Educational Studies, 43(3), 354-369.

[35] Lin, C. F., Lu, M. S., Chung, C. C., \& Yang, C. M. (2010). A comparison of problembased learning and conventional teaching in nursing ethics education. Nursing Ethics, 17(3) 373-382.

[36] Yuan, H., Williams, B. A., \& Fan, L. A. (2008). Systematic review of selected evidence on developing nursing students' critical thinking through problem-based learning. Nurse Education Today, 28(6) 657-663.

[37] Hmelo-Silver, C. E. (2004). Problem based learning: What and how do students learn? Education Psychology Review, 16(3), 235-265.

[38] Copley, J. V. (1999). Mathematics in the early years. Reston, 
VA: National Council of Teachers of Mathematics.

[39] Winterton, J., Delamare-Le Deist, F., \& Stringfellow, E. (2006). Typology of knowledge, skills and competences: clarification of the concept and prototype. Luxembourg: Office for Official Publication of the European Community.

[40] Topping, K., \& Ehly, S. (1998). Introduction to peer-assisted learning. In K. Topping \& S. Ehly (Eds.). Peer-assisted learning. Lawrence Erlbaum, Mahwah, NJ, pp 1-23.

[41] Herman, J. M., \& Knobloch, N. A. (2004). Exploring the effects of constructivist teaching on students' attitudes and performance. Proceedings from the 2nd Annual North Central Region AAAE Research Meeting. Lafayette, IN: 21-35.

[42] Erickson, D. K. (1999). A problem-based approach to mathematics instruction. Math Teach, 92(6), 516-521.

[43] Krulik, S., \& Rudnick, J. A. (1999). Innovative tasks to improve critical- and creative-thinking skills. In I. V. Stiff (Ed.), Developing mathematical reasoning in grades $K-12$ (pp. 138-145). Reston, VA: National Council of Teachers of Mathematics.

[44] Van de Walle, J. A. (2001) Elementary and middle school mathematics: teaching developmentally. Addison-Wesley Longman, New York.

[45] Kammanee, T. (2008). Science of teaching knowledge for effectiveness of teaching and learning process. Bangkok: Chulalongkorn Printing.

[46] Kuvac, M., \& Koc, I. (2019). The effect of problem-based learning on the environmental attitudes of preservice science teachers. Educational Studies, 45(1), 72-94.

[47] Sungur, S., \& Tekkaya, C. (2006). Effects of problem-based learning and traditional instruction on self-regulated learning. The Journal of Educational Research, 99(5), 307320.

[48] Tatar, E., \& Oktay, M. (2011). The effectiveness of problem-based learning on teaching the first law of thermodynamics. Research in Science \& Technological Education, 29(3), 315-332.

[49] Wilder, S. (2014). Impact of problem-based learning on academic achievement in high school: a systematic review. Educational Review, 67(4), 414-435.

[50] Wirkala, C., \& Kuhn, D. (2011). Problem-based learning in k-12 education: is it effective and how does it achieve its effects? American Educational Research Journal, 48(5), $1157-1186$.

[51] Polya, G. (1973). How to solve it. Princeton, NJ: Princeton University Press.

[52] Ministry of Education. (2006). Peraturan Menteri Pendidikan Nasional No. 22 Tahun 2006 Tentang Standar Isi. Jakarta: Depdiknas.

[53] Ennis, R. H. (1996). Critical thinking. New Jersey: Printice-Hall Inc.

[54] Arends, R. I. (2012). Learning to teach. New York: McGraw-Hill.

[55] Hair, J. F., Anderson, R. E., Tatham, R. L., \& Black, W. C. (1995). Multivariate data analysis. Englewood Cliffs, NJ: Prentice-Hall.
[56] Ultay, E. (2017). Examination of context-based problem-solving abilities of pre-service physics teachers. Journal of Baltic Science Education, 16(1), 113-122.

[57] Cook, M., \& Moyle, K. (2002). Students' evaluation of problem-based learning. Nurse Education Today, 22, 330339.

[58] Morales-Mann, E., \& Kaitell, C. A. (2001). Problem-based learning in a new Canadian curriculum. Journal of Advanced Nursing, 33(1) 13-19.

[59] Pedersen, S., \& Liu, M. (2002). The transfer of problem-solving skills from a problem-based learning environment. Journal of Research on Technology in Education, 35(2), 303-320.

[60] Iwaoka, W. T., Li, Y., \& Rhee, W. Y. (2010). Measuring gains in critical thinking in food science and human nutrition courses: The Cornell critical thinking test, problem-based learning activities, and student journal entries. Journal of Food Science Education, 9(3), 68-75.

[61] Tiwari, A., Lai, P., So, M., \& Yuen, K. (2006). A comparison of the effects of problem based learning and lecturing on the development of students' critical thinking. Medical education, 40(6), 547-554.

[62] Wright, P. (2001). School-based issues and appropriate technology. In R. C. Wicklein (Ed.), Appropriate technology for sustainable living: ITEA 50th yearbook (pp. 133- 152). Reston, VA: International Technology Education Association.

[63] Olteanu, C., \& Olteanu, L. (2013). Enhancing mathematics communication using critical aspects and dimensions of variation. International Journal of Mathematical Education in Science and Technology, 44(4), 513-522.

[64] Irwanto, Saputro, A. D., Rohaeti, E., \& Prodjosantoso, A. K. (2019). Using inquiry-based laboratory instruction to improve critical thinking and scientific process skills among preservice elementary teachers. Eurasian Journal of Educational Research, 80, 151-170.

[65] Bilgin, I., Senocak, E., \& Sozbilir, M. (2009). The effects of problem-based learning instruction on university students' performance of conceptual and quantitative problems in gas concepts. Eurasia Journal of Mathematics, Science \& Technology Education, 5(2), 153-164.

[66] Dehkordi, A. H., \& Heydarnejad, M. S. (2008). The impact of problem-based learning and lecturing on the behavior and attitudes of Iranian nursing students. Dan Med Bull, 55(4), 224-226.

[67] Sendag, S., \& Odabasi, H. F. (2009). Effects of an online problem based learning course on content knowledge acquisition and critical thinking skills. Computers \& Education, 53(1), 132-141.

[68] Argaw, A. S., Haile, B. B., Ayalew, B. T., \& Kuma, S. G. (2016). The effect of problem based learning (PBL) instruction on students' motivation and problem solving skills of physics. Eurasia Journal of Mathematics, Science and Technology Education, 13(3), 857-871.

[69] Gilbert, J. K. (2006). On the nature of "context" in chemical education. International Journal of Science Education, 28(9), 957-976. 